\title{
STRAIGHTFORWARD, ECONOMICAL PROCEDURES FOR MICROSCALE ELLMAN'S TEST FOR CHOLINESTERASE INHIBITION AND REACTIVATION
}

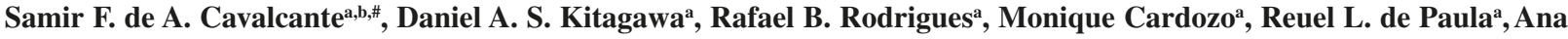 \\ Beatriz de A. Correa ${ }^{a}$ and Alessandro B. C. Simas ${ }^{\mathrm{b}, *}$ \\ anstituto de Defesa Química, Biológica, Radiológica e Nuclear, Exército Brasileiro, Avenida das Américas 28705, 23020-470 \\ Rio de Janeiro - RJ, Brasil \\ 'Instituto de Pesquisas de Produtos Naturais Walter Mors (IPPN), Centro de Ciências da Saúde, Universidade Federal do Rio de \\ Janeiro, 21941-902 Rio de Janeiro - RJ, Brasil
}

Recebido em 24/04/2018; aceito em 23/07/2018; publicado na web em 22/08/2018

\begin{abstract}
Straightforward, microscale, Ellman's cholinesterase test procedures are presented, useful for screening of novel compounds aiming at neurodegenerative diseases and antidotes towards nerve agents and pesticides. Herein, we detail the different procedure features and set forth guidelines on experimental choices researchers may make. The detailed procedure lowers the costs for Ellman's test, what is highly desirable for low-budget groups in science-lagging and developing countries.
\end{abstract}

Keywords: Ellman's test; cholinesterase; neurodegenerative diseases; nerve agents; pesticides.

\section{INTRODUCTION}

Cholinesterases are serine-estearases, which hydrolyze acetylcholine (ACh), the major neurotransmitter in parasympathetic neurotransmission, interrupting stimulation of cholinergic receptors. ${ }^{1,2}$ Their inhibition leads to two different outcomes according to type of inhibitor used. Reversible inhibitors have been used for neurodegenerative diseases, e.g., Alzheimer's disease (AD), for which one therapeutic approach is to increase ACh concentration into the synaptic cleft, ameliorating memory loss. ${ }^{3}$ Irreversible inhibitors, such as organophosphorus compounds, used as pesticides and nerve agents, irreversibly inhibit cholinesterases, leading to overstimulation of neuromuscular junctions and other structures, which may be fatal. As there are few drugs approved for AD and there is no "universal antidote" against toxic organophosphorus compounds, research on these subjects is clearly warranted. ${ }^{4}$

The Ellman's test is a spectrophotometry-based assay to measure thiol groups in different matrices. Since its disclosure, ${ }^{5,6}$ many papers have put forward modifications of the original procedure adjusted to specific needs. ${ }^{7}$ The relative importance of such modifications sometimes is not clear to those who do not possess experience on such assays. Herein, we report a straightforward, reproducible, customable, safer and validated Ellman's procedure using 96-wells microplates, to test cholinesterase activity for both inhibition and reactivation. For being economical and rendering extensive preliminary experimentation unnecessary, it could be particularly useful to low-budget groups in science-lagging and developing countries.

The reactions of Ellman's test for cholinesterase activity are depicted in Figure 1. Acetylthiocholine halide (1, X-either chloride or iodide), in presence of a non-inhibited cholinesterase (2), is hydrolyzed to acetate (3) and thiocholine (4). Then, the latter reacts with 5,5'-dithiobis(2-nitrobenzoic) acid (DTNB, 5, Ellman's reagent), affording the anionic form of 5-mercapto-2-nitrobenzoic acid (6). The reaction is monitored at $412 \mathrm{~nm}$. Higher absorbance means high enzyme activity. Activities of either acetylcholinesterase (AChE,

*e-mail: abcsimas@nppn.ufrj.br

\#alternative e-mail: samir.cavalcante@eb.mil.br
EC 3.1.1.7) or butyrylcholinesterase (BChE, EC 3.1.1.8) may be evaluated by this methodology. ${ }^{6-9}$

The Ellman's assay is useful to screen either novel agents against neurodegenerative diseases or novel antidotes. For neurodegenerative diseases where the cholinergic hypothesis is considered, such as $\mathrm{AD}$, comparison to standard, clinical inhibitors, e.g., physostigmine, rivastigmine or donepezil, is required in the assays. The use of organophosphates inhibitors, such as pesticides, nerve agents and their surrogates, allows the study of novel antidote candidates. ${ }^{8-10}$ Additionally, it may be useful for evaluation of exposure to organophosphate by analysis of blood and tissue samples. However, potential interferences such as thiol residues found in these matrices, hemoglobin absorbance at $412 \mathrm{~nm}$, as well BChE simultaneous reaction, need to be addressed. ${ }^{9,10}$

At the outset, we noticed that some reports dealt with rather large quantities of reagents and enzymes, which are cost-prohibitive. Inexperienced researchers may already spend considerable resources (enzyme, reagents) in training for such assays, especially if they do not have practice on extraction and use of cholinesterases from tissue extracts or serum. In fact, based upon the available literature on Ellman's test with 96 - and 384-wells ${ }^{11-15}$ we went through, we realized that a straightforward, detailed and commented microvolume-based protocol might greatly benefit those researchers and, at the same time, guide further customization.

\section{EXPERIMENTAL SECTION}

\section{Materials and reagents}

Acetylthiocholine iodide, DTNB, lyophilized acetylcholinesterase (AChE) from Electrophorus eel (1000 U per mg protein, Type $\mathrm{V}-\mathrm{S}$, C2888), pralidoxime iodide (2-PAM), paraoxon (POX), dimethyl sulfoxide (DMSO, biological grade, dry, oxygen-free sealed bottle), isopropanol, sodium hydroxide (pellets), sodium phosphate monobasic hydrate and sodium phosphate dibasic dihydrate were purchased from Sigma-Aldrich Brazil (São Paulo - SP, Brazil). Bovine Serum Albumine (BSA) was provided by IDQBRN Biological Defense Laboratory. Technical grade sodium hypochlorite was provided by IDQBRN Decontamination Team. Hydrochloric acid was 


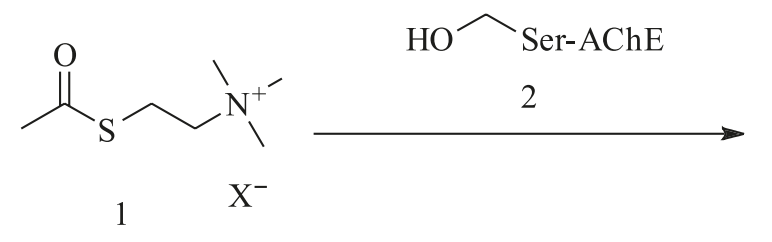<smiles>CC(=O)[OH2+]</smiles><smiles>C[N+](C)(C)CCSSc1ccc([N+](=O)[O-])c(C(=O)O)c1</smiles>

Figure 1. Reactions of Ellman's test

purchased from Vetec (Rio de Janeiro - RJ, Brazil). Trimedoxime dibromide (TMB) and obidoxime dichloride (OBD) were synthesized according to literature and physical data thereof were compatible. ${ }^{16,17}$ Purified water was obtained from Millipore Milli-Q system (18.2 M $\Omega$ $\mathrm{cm}$ at $25{ }^{\circ} \mathrm{C}$, Millipore Brazil, São Paulo - SP, Brazil). Molecular Devices UV SpectraMax Plus 384 microplate reader (Molecular Devices, San Jose, California, USA), Kasvi 96-wells microplates (Kasvi Brasil, São José dos Pinhais - PR, Brazil), Gilson single channel (Gilson Inc., Middleton, Wisconsin, USA) and Eppendorf 8-channel (Eppendorf Brasil, São Paulo - SP, Brazil) pipettes and disposable tips were used for all assays. $\mathrm{pH}$ was determined using Quimis pHmeter Q400AS (Quimis, Diadema - SP, Brazil). All tests were performed in triplicate, in three different assays, by at least three different operators, measured at $24{ }^{\circ} \mathrm{C} \pm 2{ }^{\circ} \mathrm{C}$. All disposable materials and glassware were decontaminated with aqueous solution containing $10 \% \mathrm{w} / \mathrm{v} \mathrm{NaOH}$ and $10 \% \mathrm{w} / \mathrm{v} \mathrm{NaClO}$ per $48 \mathrm{~h}$ at room temperature before correct destination.

\section{Preparation of stock and test solutions}

Phosphate Buffer Solution (PBS) $0.12 \mathrm{~mol} \mathrm{~L}^{-1}$, pH $7.60 \pm 0.10$ was prepared with $16.46 \mathrm{~g}$ of $\mathrm{Na}_{2} \mathrm{HPO}_{4} \cdot 2 \mathrm{H}_{2} \mathrm{O}$ and $3.71 \mathrm{~g}$ of $\mathrm{NaH}_{2} \mathrm{PO}_{4}$. $\mathrm{H}_{2} \mathrm{O}$ in $1 \mathrm{~L}$ of purified water. $\mathrm{pH}$ adjustment was done with aqueous $\mathrm{HCl}$ or $\mathrm{NaOH} 1 \mathrm{~mol} \mathrm{~L}^{-1}$. DTNB was at $0.4 \mathrm{mg} \mathrm{mL}^{-1}$ in PBS and acetylthiocholine iodide $1 \mathrm{mmol} \mathrm{L}^{-1}$ in PBS. Stock solutions of standard antidotes were prepared in DMSO at $10 \mathrm{mmol} \mathrm{L}^{-1}$ and diluted in PBS to achieve the test solution at 9000,900 and $90 \mu \mathrm{mol} \mathrm{L}^{-1}$ prior to use $\left(1000,100\right.$ and $10 \mu \mathrm{mol} \mathrm{L}^{-1}$ in wells, respectively, after all dilutions) to avoid precipitation and vortexed before use. POX test solution was freshly prepared in isopropanol at $200 \mu \mathrm{mol} \mathrm{L}^{-1}(11 \mu \mathrm{mol}$ $\mathrm{L}^{-1}$ in wells after all dilutions). Acetylcholinesterase stock solution was prepared by dilution of commercial lyophilized enzyme in PBS to achieve $125 \mathrm{U} \mathrm{mL}^{-1}\left(0.75 \mathrm{U} \mathrm{mL}^{-1}\right.$ in each well after all dilutions $)$, in accordance to package content, and stabilized with $1 \%$ BSA. All solutions were stored at $0{ }^{\circ} \mathrm{C}$ prior to use, except for the enzyme solution, which was stored at $-20^{\circ} \mathrm{C}$. This stabilized solution stored at $-20^{\circ} \mathrm{C}$ can be used at least for six months.

\section{Data analysis}

Data are expressed in mean \pm standard deviation from three different measurements obtained from three different assays. Microsoft Excel® 2007 was used for calculations.

\section{Ellman's test procedures}

Procedure for cholinesterase inhibition Ellman's test

Set the instrument temperature to the desired range and read the absorbance of empty microplate. In a clean, 10-mL glass vial, add $120 \mu \mathrm{L}$ of AChE $125 \mathrm{U} \mathrm{mL}^{-1}$ and $6880 \mu \mathrm{L}$ of PBS (amount enough for 96 wells). Pipette $70 \mu \mathrm{L}$ of this solution $\left(2.14 \mathrm{U} \mathrm{mL}^{-1}\right)$ to each well and add $80 \mu \mathrm{L}$ of DTNB $0.4 \mathrm{mg} \mathrm{mL}^{-1}, 10 \mu \mathrm{L}$ of POX solution (for positive control, absorbance $\mathrm{L}_{\mathrm{i}}$ ) or $10 \mu \mathrm{L}$ of PBS (for negative control, absorbance $\mathrm{L}_{0}$ ) and $20 \mu \mathrm{L}$ of PBS. After waiting for desired time for inhibition reaction, add $20 \mu \mathrm{L}$ of acetylthiocholine iodide $1 \mathrm{mmol} \mathrm{L}^{-1}$ and read at $412 \mathrm{~nm}$ in different times to calculate enzyme inhibition.

Procedure for cholinesterase reactivation Ellman's test (screening of antidotes)

Set the instrument temperature to the desired range and read the absorbance of empty microplate. In a clean, 10-mL glass vial, add $120 \mu \mathrm{L}$ of AChE $125 \mathrm{U} \mathrm{mL}^{-1}$ and $6880 \mu \mathrm{L}$ of PBS (amount enough for 96 wells). Pipette $70 \mu \mathrm{L}$ of this solution $\left(2.14 \mathrm{U} \mathrm{mL}^{-1}\right)$ to each well and, $80 \mu \mathrm{L}$ of DTNB $0.4 \mathrm{mg} \mathrm{mL}^{-1}, 10 \mu \mathrm{L}$ of POX solution (for positive control, absorbance $\mathrm{L}_{\mathrm{i}}$ ) or $10 \mu \mathrm{L}$ of PBS (for negative control, absorbance $\mathrm{L}_{0}$ ) and wait for assay time. Add $20 \mu \mathrm{L}$ of the antidote 
standard solution (or test compound, absorbance $\mathrm{L}_{\mathrm{r}}$ ) and wait for desired time for reactivation reaction (we set $10 \mathrm{~min}$ ). Then, add $20 \mu \mathrm{L}$ of acetylthiocholine iodide $1 \mathrm{mmol} \mathrm{L}^{-1}$ and read at $412 \mathrm{~nm}$ in different times to calculate enzyme reactivation.

\section{RESULTS AND DISCUSSION}

\section{General comments}

In carrying out the Ellman's assays, special care should be taken with the toxicity of the employed inhibitors, as organophosphorus compounds are poisonous. Cholinesterases extraction from biological source ${ }^{18,19}$ may be an alternative to commercial sources in budget-tight laboratories. Stability of enzyme stock solutions must be considered, as well as the effect on cholinesterases by solvents in assayed compounds' solutions. Background effects on absorbance must also be considered for plates and compound solutions, avoiding calculating errors and invalid data. Such effects are relevant in measurements of Cholinesterase activity in tissue and blood samples in routine diagnosis. ${ }^{5,6,9,10,19-21}$ Interference caused by thiol residues found in these matrices requires different approaches for its minimization, such as sample dilution or previous treatment of biological matrix with DTNB..$^{5,6,10}$ Hemoglobin absorbance at $412 \mathrm{~nm}$ could also be a potential source of error, which might require the use of a different wavelength or development of novel chromophores. ${ }^{9,10,21-23} \mathrm{BChE}$ simultaneous reaction might also be a limitation to this methodology. Washing with saline solution or the use of specific BChE inhibitors, such as ethopropazine are possible solutions. ${ }^{9,10}$

\section{Inhibition of cholinesterase}

Cholinesterase inhibition may be calculated using the following equation, $\% \mathrm{I}=\left[\left(\mathrm{L}_{0}-\mathrm{L}_{\mathrm{i}}\right) / \mathrm{L}_{0}\right] \times 100$, being $\% \mathrm{I}$ the inhibition percent, $\mathrm{L}_{0}$ the absorbance without inhibitor and $\mathrm{L}_{\mathrm{i}}$ the absorbance with inhibitor. Results after AChE inhibition for 10 and 30 minutes using POX $11 \mu \mathrm{mol} \mathrm{L}{ }^{-1}$ are shown in Table 1. POX concentration was defined according to the literature, ${ }^{11}$ although higher concentrations might be used. Nevertheless, as organophosphorus compounds (as POX) are potent cholinesterase inhibitors, it is important to avoid concentrations that may pose unnecessary hazard to the operator. Usually, papers have described organophosphorus concentrations ranging from $10^{-5}$ to $10^{-9} \mathrm{~mol} \mathrm{~L}{ }^{-1} \cdot{ }^{8,11-13}$ One can check the suitable inhibition level by performing the assay with different inhibitor concentrations, keeping in mind not to fully inhibit the enzyme. Residual AChE activity avoids misinterpretation of reactivation data due to reactions between test chemicals and excess of inhibitor, for example. According to our tabulated data (Table 1), inhibition by POX, a potent cholinesterase inhibitor, was immediate, keeping steady over time. However, we decided to use $10 \mathrm{~min}$ as inhibition time in this case. It is noteworthy that inhibition reaction time, level and concentration are customable by the operator. This makes the procedure herein presented, used in our research on novel antidote candidates against different organophosphorus compounds, easily adjustable.

$\mathrm{pH}$ is important as it may interfere in enzyme activity, as we have noted in our trials (data not shown). All experiments must be performed at the same $\mathrm{pH}$. Literature recommends $\mathrm{pH}$ values close to physiological $\mathrm{pH}$, usually varying between 7.4-7.8, the optimal $\mathrm{pH}$ range for the enzyme. ${ }^{7-15}$ In our procedures, we set it at $7.60 \pm 0.10$. We also identified that isopropanol and DMSO (used as solvents in solutions of assay chemicals) interfered on enzyme activity, if at high concentrations. In fact, in our conditions, we detected enzyme inhibition and conflicting measurements for concentrations higher than $10 \%$ for isopropanol and 5\% for DMSO (data not shown). Due to these observations, we decided to use PBS both as negative control and for dilutions of antidotes (or test compounds), which led to consistent results.

\section{Reactivation of cholinesterase}

Cholinesterase reactivation may be calculated by using the following equation, $\% \mathrm{R}=\left[\left(\mathrm{L}_{\mathrm{r}}-\mathrm{L}_{\mathrm{i}}\right) /\left(\mathrm{L}_{0}-\mathrm{L}_{\mathrm{i}}\right)\right] \times 100$, being $\% \mathrm{R}$ the reactivation percent, $\mathrm{L}_{0}$ the absorbance without inhibitor, $\mathrm{L}_{\mathrm{i}}$ the absorbance with inhibitor and $\mathrm{L}_{\mathrm{r}}$ the absorbance after addition of reactivator. After 10 min-inhibition with $11 \mu \mathrm{mol} \mathrm{L} \mathrm{L}^{-1}$ of POX, the enzyme reactivation were effected by standard antidotes obidoxime dichloride (OBD), trimedoxime dibromide (TMB) and pralidoxime iodide (2-PAM) as shown in Table 2.

The selected concentrations for antidotes were based on the literature. It is known that higher concentrations of oximes, clinical reactivators of choice, may react with Ellman's reagents (oximolysis). To minimize this error, estearic activity of oximes (or compounds) may be evaluated via reaction with DTNB and acetylthiocholine in absence of enzyme and inhibitor. In cases where increase of absorbance was noted, as we have seen with some test compounds in our research, the operator must take the value as background. This is a limitation of Ellman's test, depending on the type of compounds to be screened. It is also known that oximes may act as weak cholinesterase inhibitors, ${ }^{24-26}$ which may explain the reduced reactivation potential for pralidoxime and obidoxime observed at $1000 \mu \mathrm{mol} \mathrm{L} \mathrm{L}^{-1}$ in comparison to other assayed concentrations. This outcome depends

Table 1. AChE Inhibition results (mean \pm SD)

\begin{tabular}{lccccccc}
\hline \multirow{2}{*}{ POX \% Inhibition } & \multicolumn{7}{c}{ Reading Time (min) } \\
\cline { 2 - 7 } & 5 & 10 & 15 & 20 & 25 & 30 \\
\hline Inhibition time= 10min & $95.0(1.4)$ & $94.5(1.1)$ & $94.6(1.4)$ & $94.5(1.6)$ & $94.1(1.4)$ & $94.0(1.4)$ & $94.5(1.3)$ \\
Inhibition time= 30min & $95.3(0.3)$ & $95.3(0.3)$ & $95.3(0.3)$ & $95.0(0.3)$ & $93.2(3.4)$ & $94.7(0.2)$ & $95.0(0.3)$ \\
\hline
\end{tabular}

Table 2. AChE reactivation $(\%$, mean $\pm \mathrm{SD})$

\begin{tabular}{cccccccccc}
\hline \multirow{2}{*}{$\begin{array}{c}\text { Reading Time } \\
(\mathrm{min})\end{array}$} & OBD & OBD & OBD & TMB & TMB & TMB & 2-PAM & 2-PAM & 2-PAM \\
& 1000 & 100 & 10 & 1000 & 100 & 10 & 1000 & 100 \\
\hline 10 & $52.9(1.3)$ & $56.3(0.2)$ & $22.9(2.8)$ & $33.7(1.9)$ & $31.1(2.7)$ & $9.5(1.7)$ & $18.7(1.4)$ & $14.4(2.9)$ & $5.6(2.2)$ \\
20 & $48.7(2.6)$ & $71.3(2.0)$ & $39.4(2.2)$ & $67.9(1.1)$ & $57.7(3.7)$ & $17.3(0.7)$ & $29.9(1.3)$ & $31.6(0.5)$ & $11.3(1.5)$ \\
30 & $60.4(2.5)$ & $84.3(1.9)$ & $53.0(1.5)$ & $79.4(1.1)$ & $65.8(1.0)$ & $23.8(2.7)$ & $38.4(2.7)$ & $45.1(5.4)$ & $16.9(2.7)$ \\
\hline
\end{tabular}


on different oxime structural features, such as number of pyridinium rings, linker length, etc. The maximum attainable concentration in vivo is $100 \mu \mathrm{mol} \mathrm{L} \mathrm{L}^{-1}$. Nevertheless, assays at higher concentrations are valuable for further development of cholinesterase inhibitors for neurodegenerative diseases. ${ }^{25-29}$

With our procedure, spontaneous reactivation and enzymatic aging may also be accessed. For instance, Soman ( $O$-pinacolyl methylphosphonofluoridate) results in a phosphonylated enzyme, which spontaneously disproportionate to a stable, ionized phosphonate derivative and, thus, is aged. ${ }^{30,31}$ We have also successfully employed nerve agents surrogates using the described methodology. ${ }^{32-34}$

\section{CONCLUSIONS}

We herein report straightforward, adjustable, reliable and economical Ellman's test procedures for screening of novel inhibitors and reactivators. Such microscale protocols have been successfully employed in our own research to investigate spontaneous reactivation, oximolysis and enzymatic aging. The detailed protocols set forth a number of guidelines intended to assist newcomers in the study on acetylcholinesterase inhibition and reactivation. We are currently applying such adjustable Ellman's test to enzymatic kinetics procedures using lyophilized enzymes, plasma, blood and bovine brain extracts. Finally, these protocols have been useful to the experiments with nerve agents' surrogates in our laboratory.

\section{ACKNOWLEDGEMENTS}

Authors would like to thank M. Pohanka and K. Kuča for providing relevant literature and advice. This work has been supported by the Organisation for the Prohibition of Chemical Weapons - OPCW "Research Projects Support Programme" L/ICA/ICB/201062/15.

\section{REFERENCES}

1. Quinn, D. M.; Chem. Rev. 1998, 87, 955.

2. Taylor, P.; J. Biol. Chem. 1991, 266, 4025.

3. Kumar, A.; Singh, A.; Ekavali; Pharmacol. Rep. 2015, 67, 195.

4. Gorecki, L.; Korabecny, J; Musilek, K.; Malinak, D.; Nepovimova, E.; Dolezal, R.; Jun, D.; Soukup, O.; Kuča, K.; Arch. Toxicol. 2016, 90 , 2831.

5. Ellman, G. L.; Arch. Biochem. Biophys. 1959, 82, 70.

6. Ellman, G. L.; Courtney, K. D.; Andres Jr., V.; Featherstone, R. M.; Biochem. Pharmacol.1961, 7, 88.

7. Worek, F.; Eyer, P.; Thiermann, H.; Drug Test. Anal. 2012, 4, 282.

8. Pohanka, M.; Jun, D.; Kuča, K.; Talanta 2008, 77, 451.

9. Nepovimova, E.; Korabecny, J.; Dolezal, R.; Nguyen, T. D.; Jun, D.; Soukup, O.; Pasdiorova, M.; Jost, P.; Muckova, L.; Malinak, D.; Gorecki, L.; Musilek, K.; Kuča, K.; Toxicol. Res. 2016, 5, 1012.
10. Ždárová-Karasová, J.; Kuča, K.; Jun, D.; Bajgar, J.; Chem. Listy 2010, 104, 46.

11. Jarvinen, P. P.; Fallarero, A.; Gupta, S.; Mohan, G. C.; Hatakka, A. I.; Vuorela, P. M.; Comb. Chem. High Throughput Screening 2010, 13, 278.

12. Pohanka, M.; Hrabinova, M.; Kuča, K.; Simonato, J. P.; Int. J. Mol. Sci. 2011, 12, 2631.

13. Pohanka, M.; Jun, D.; Kuča, K.; J. Enzyme Inhib. Med. Chem. 2008, 23, 781.

14. Järvinen, P. P.; Vuorela, P.; Hatakka, A.; Fallarero, A.; Anal. Biochem. 2011, 408, 166.

15. Dingova, D.; Leroy, J.; Check, A.; Garaj, V.; Krejci, E.; Hrabovska, A.; Anal. Biochem. 2014, 462, 67.

16. Kuča, K.; Cabal, J.; Patocka, J.; Kassa, J.; Lett. Org. Chem. 2004, 1, 84.

17. Musílek, K.; Lipka, L.; Račáková, V.; Kuča, K.; Jun, D.; Dohnal, V.; Doležal, M.; Chem. Papers 2006, 60, 48.

18. Reiner, E.; Sinko, G.; Skrinjarić-Spoljar, M.; Simeon-Rudolf, V.; Arh. Hig. Rada. Toksikol. 2000, 51, 13.

19. Linhares, A. G.; Assis, C. R.; Siqueira, M. T.; Bezerra, R. S.; Carvalho Jr., L. B.; Hum. Exp. Toxicol. 2013, 32, 837.

20. Ždárová-Karasová, J.; Bajgar, J.; Jun, D.; Pavliková, R.; Kuča, K. Neurotox. Res. 2009, 16, 356.

21. Worek, F.; von der Wellen, J.; Mušilek, K.; Kuča, K.; Thiermann, H. Arch. Toxicol. 2012, 86, 1379.

22. George, P. M.; Abernethy, M. H.; Clin. Chem. 1983, 29, 365.

23. Sinko, G.; Kovarik, Z.; Reiner, E.; Simeon-Rudolf, V.; Stojan, J.; Biochimie 2011, 93, 1797.

24. Sepsova, V.; Karasova, J. Z.; Korabecny, J.; Dolezal, R.; Zemek, F.; Bennion, B. J.; Kuca, K.; Int. J. Mol. Sci. 2013, 14, 16882.

25. Kloog, Y.; Sokolovsky, M.; Mol. Pharmacol. 1985, 27, 418.

26. Lima, J. A.; Cavalcanti, L. P. A. N.; Aguiar, A. P.; Rezende, C. M.; Lima, K. S. C.; Lima, A. L. S.; Defence Life Science Journal 2017, 2, 363.

27. Sakurada, K.; Ikegaya, H.; Ohta, H.; Akutsu, T.; Takatori, T.; Toxicol. Lett. 2006, 166, 255.

28. Tattersall, J. E. H.; Br. J. Pharmacol.1993, 108, 1006.

29. Kuča, K.; Kassa, J.; J. Enzyme Inhib. Med. Chem. 2003, 18, 529.

30. Quinn, D. M.; Topczewski, J.; Yasapala, N.; Lodge, A.; Molecules 2017, 22, 1464.

31. Kovalevsky, A.; Blumenthal, D. K.; Cheng, X.; Taylor, P.; Radic, Z.; Ann. N. Y. Acad. Sci. 2016, 1378, 41.

32. Chambers, J. E.; Chambers, H. W.; Funck, K. E.; Meek, E. C.; Pringle, R. B.; Ross, M. K.; Chem. Biol. Interact. 2016, 259, 154.

33. Coban, A.; Carr, R. L.; Chambers, H. W.; Willeford, K. O.; Chambers, J. E.; Toxicol. Lett. 2016, 248, 39.

34. Cavalcante, S. F. A.; de Paula, R. L.; Kitagawa, D. A. S.; Barcellos, M. C.; Simas, A. B. C.; Granjeiro, J. M.; J. Phys.: Conf. Ser. 2018, 975, 012020. 